\title{
Pertumbuhan dan Hasil Dua Belas Genotipe Kacang Hijau pada Beberapa Dosis Pupuk Kandang Sapi di Lahan Ultisol
}

\author{
Growth and Yield of Twelve Mung Bean Genotypes at Several Cow Manure \\ Doses in Ultisol
}

\author{
Andria $^{1}$, Catur Herison ${ }^{1 *}$, Sigit Sudjatmiko ${ }^{1}$, Nurwita Dewi ${ }^{2}$ \\ IProgram Studi Agroekoteknologi Jurusan Budidaya Pertanian Fakultas Pertanian \\ Universitas Bengkulu. \\ ${ }^{2}$ Balai Besar Bioteknologi dan Sumberdaya Genetik Pertanian (BB BIOGEN) \\ *: catur_herison@unib.ac.id
}

\begin{abstract}
One major problem of low mungbean production in Indonesia is the lack of high yielding varieties for marginal land. A study was done with an objective to compare growth and yield of twelve mung bean genotypes on ultisol fertilized with several doses of cow manure. Twelve mung bean genotypes were grown in a field under a randomized complete block design arranged in a Split Plot Design with 3 replications. The Main Plots were four doses of cow manure, i.e. 0, 3, 6 or 9 ton.ha-1 and the Sub-Plots were twelve mungbean genotypes, i.e. VR 3, VR 61, VR 88, VR 200, VR 204 K, VR 213 K, VR 266 ct, VR 341, VR 368, $V R 601 \mathrm{~m}$, VR 222 Walet and VR 1074 Vinna-1. The result showed that the interaction between cow manure doses and mungbean genotypes was only occured on number of leaf. Genotype VR 61 demonstrated the highest plant stature, the greatest pod number, the heafiest pod and seeds per plant. Increasing dose of cow manure until 9 tons. $\mathrm{h}^{-1}$ did not reach the optimum level for the growth and yield of mungbean genotypes yet, except on the number of leaf variable on genotype VR 3, VR 88, VR 200, VR 266 ct and VR 601.
\end{abstract}

Key words : cow manure, genotypes, mungbean, ultisol

\begin{abstract}
ABSTRAK
Rendahnya produktivitas kacang hijau ditingkat petani salah satunya adalah disebabkan oleh kurang tersedianya varietas unggul. Penelitian ini bertujuan untuk membandingkan pertumbuhan dan hasil dua belas genotipe kacang hijau pada berbagai taraf dosis pupuk kandang sapi di lahan ultisol, menggunakan Rancangan Acak Kelompok Lengkap Split Plot dengan tiga ulangan. Empat taraf dosis pupuk kandang sapi, 0, 3, 6, dan 9 ton ha ${ }^{-1}$ sebagai petak utama dan dua belas jenis genotip kacang hijau, VR 3, VR 61, VR 88, VR 200, VR 204 K, VR 213 K, VR 266 ct, VR 341, VR 368, VR 601 m, VR 222 Walet, dan VR 1074 Vinna-1 sebagai anak petak. Hasil penelitian menunjukkan terdapat interksi antara dosis pupuk kandang sapi dengan genotipe kacang hijau pada variabel jumlah daun. Genotipe VR 61 memiliki nilai tertinggi pada pertumbuhan tinggi tanaman, jumlah polong, bobot polong, dan bobot biji per tanaman. Hasil biji kering genotipe VR $61107.42 \mathrm{~g} \mathrm{unit}^{-1}$ percobaan. Peningkatan dosis pupuk kandang sapi hingga 9 ton ha ${ }^{-1}$ belum mencapai titik optimum untuk pertumbuhan dan hasil genotipe kacang hijau, kecuali pertumbuhan jumlah daun genotipe VR 3, VR 88, VR 200, VR 266 ct, dan VR 601 m.
\end{abstract}

Kata kunci :dosis, genotipe, kacang hijau, pupuk kandang sapi, ultisol 


\section{PENDAHULUAN}

Kacang hijau (Vigna radiata L.) merupakan salah satu komoditas tanaman kacang-kacangan yang banyak dikonsumsi masyarakat Indonesia, seperti olahan bahan industri, olahan bahan pangan, bubur kacang hijau, isi onde-onde, dan sayuran kecambah (tauge) (Atman, 2007). Tanaman ini memiliki potensi yang tinggi untuk dikembangkan, namun masih kurang mendapat perhatian dari petani karena tingkat produksi dan keuntungan yang termasuk rendah. Menurut Hidayah dan Susanto (2008), kendalanya antara lain adalah kurang tersedianya varietas unggul, kekeringan atau kelebihan air, teknik bercocok tanam belum optimal, gangguan Organisme Pengganggu Tanaman (OPT), dan masalah sosial ekonomi.

Berdasarkan pola perhitungan Neraca Bahan Makanan (NBM) konsumsi kacang hijau di Indonesia masih tergolong rendah antara 1.1 s.d $1.47 \mathrm{~kg} \mathrm{kapita}^{-1}$ tahun $^{-1}$ (Ditjen Tanaman Pangan, 2012). Sementara agar kebutuhannya terpenuhi konsumsi kacang hijau harus mencapai $2.5 \mathrm{~kg}$ kapita $^{-1}$ tahun $^{-1}$. Tantangan pengembangan kacang hijau adalah peningkatan produktivitas di lahan kering dan mempertahankan kualitas lahan untuk berproduksi lebih lanjut, lahan kering seperti ultisol umumnya tergolong masam dan miskin hara (Kasno, 2007).

Indonesia memiliki lahan ultisol dengan sebaran luas mencapai 45794000 ha atau sekitar $25 \%$ dari total luas daratan Indonesia. Luas ultisol di Provinsi Bengkulu mencapai 705161 ha (Mulyani et al., 2004). Ultisol memiliki kandungan $\mathrm{pH}$ yang berkisar 3.5-5.0 atau disebut masam dan kandungan unsur Al, Fe dan Mn tinggi, selain itu sifat biologi tanah yang rendah karena kurangnya kandungan bahan organik dan unsur hara dalam tanah (Utomo, 2008).
Bahan organik selain dapat meningkatkan kesuburan tanah dan $\mathrm{pH}$ tanah juga mempunyai peran penting dalam memperbaiki sifat fisik tanah, kimia tanah, dan biologi tanah, meningkatkan agregasi tanah, memperbaiki aerasi dan perkolasi, serta membuat struktur tanah menjadi lebih remah dan mudah diolah (Subowo et al., 1990).

Pemberian berbagai jenis dan takaran dosis pupuk kandang (sapi, ayam, dan kambing) dapat memperbaiki sifat fisik tanah, yaitu menurunkan bobot isi serta meningkatkan porositas tanah dan laju permeabilitas (Adimihardja et al., 2000). Pupuk kandang sapi berasal dari kotoran padat dan cair (urin) ternak sapi yang telah bercampur dengan sisa-sisa makanan dan material alas kandang (Musnawar, 2006). Dijelaskan oleh Nurmawati dan Anang (2000), hara yang terdapat didalam pupuk kandang sapi berkadar rata-rata $0.56 \% \mathrm{~N}$, $13.05 \% \mathrm{C}, 27 \% \mathrm{C} / \mathrm{N}, 0.26 \% \mathrm{P}, 0.16 \% \mathrm{~K}$, $0.01 \% \mathrm{Ca}, 0.18 \% \mathrm{Mg}, 67.38 \% \mathrm{H}_{2} \mathrm{O}, 7.01$ $\mathrm{pH} \mathrm{H}_{2} \mathrm{O}, 6.76 \mathrm{pH}$ KCL. Hasil penelitian Afif et al. (2014) mendapatkan bahwa tanaman kacang dengan laju asimilasi terbesar ada pada perlakuan pemberian pupuk kandang sapi dibanding pupuk kandang lainnya.

Tujuan penelitian ini adalah untuk membandingkan pertumbuhan dan hasil dua belas genotipe kacang hijau pada berbagai taraf dosis pupuk kandang sapi di lahan ultisol.

\section{METODE PENELITIAN}

Penelitian ini menggunakan Rancangan Acak Kelompok Lengkap Split Plot dengan 3 ulangan. Dosis pupuk kandang sapi, $\mathrm{D}_{0}=0$ ton ha- $\mathrm{D}_{1}=3$ ton ha $\mathrm{D}^{-1}, \mathrm{D}_{2}=6$ ton $\mathrm{ha}^{-1}$, dan $\mathrm{D}_{3}=9$ ton ha ${ }^{-1}$, sebagai petak utama dan dua belas genotipe kacang hijau, $\mathrm{G}_{1}=\operatorname{VR} 3, \mathrm{G}_{2}=\operatorname{VR} 61, \mathrm{G}_{3}=\operatorname{VR} 88, \mathrm{G}_{4}=$ 
VR $200 \mathrm{G}_{5}=\mathrm{VR} 204 \mathrm{~K}, \mathrm{G}_{6}=\mathrm{VR} 213 \mathrm{~K}$, $\mathrm{G}_{7}=\mathrm{VR} 266$ ct, $\mathrm{G}_{8}=\mathrm{VR} 341, \mathrm{G}_{9}=\mathrm{VR}$ $368, \mathrm{G}_{10}=\mathrm{VR} 601 \mathrm{~m}, \mathrm{G}_{11}=$ VR 222 walet, dan $\mathrm{G}_{12}=$ VR 1074 Vinna-1, sebagai anak petak.

Persiapan lahan dimulai dengan membersihkan area lahan yang akan digunakan dari gulma alang-alang dan perdu liar, menggunakan sabit dan parang. Kemudian lahan dibajak menggunakan traktor sedalam $20 \mathrm{~cm}$ yang selanjutnya dilakukan penggemburan pertama menggunakan cangkul. Setelah itu dibuat petakan $6 \mathrm{~m} \mathrm{x}$ $2.5 \mathrm{~m}$ dengan jarak antar unit percobaan $0.5 \mathrm{~m}$. Selanjutnya aplikasi pupuk kandang sapi sesuai perlakuan.

Penanaman dilakukan dengan cara menanam langsung 2-3 benih ke dalam lubang tanam dengan jarak tanam $25 \mathrm{~cm} \mathrm{x}$ $25 \mathrm{~cm}$. Pemupukan dengan dosis urea 50 $\mathrm{kg} \mathrm{ha}^{-1}$, KCL $100 \mathrm{~kg} \mathrm{ha}^{-1}$, dan SP-36 $150 \mathrm{~kg}$ $\mathrm{ha}^{-1}$ diberikan sebanyak dua kali.

Pemeliharaan tanaman meliputi penyiraman, penyulaman, penjarangan, penyiangan, dan pengendalian OPT. Pengairan dilakukan apabila tidak turun hujan dan kondisi tanah dalam keadaan kering. Penyulaman dilakukan terhadap tanaman yang tidak tumbuh dan atau pertumbuhannya tidak normal dengan menggunakan benih serupa pada tujuh hari setelah tanam (hst). Penjarangan dilakukan agar tanaman seragam pertumbuhannya dengan cara mencabut dan menyisakan satu tanaman per lubang tanam yang dilakukan 14 hst. Penyiangan gulma dilakukan secara manual dengan cara mencabut gulma dan menyingkirkannya dari lahan penelitian. Untuk pengendalian hama kutu daun dan ulat penggerek polong dilakukan penyemprotan rutin satu kali seminggu setelah tanaman berbuah dengan menggunakan larutan insektisida berbahan aktif profenopos 500 $\mathrm{g}^{-1}$ air dengan konsentrasi $2 \mathrm{ml}, \mathrm{L}^{-1}$.

Panen dilakukan ketika polong sudah berwarna hitam atau coklat, dengan cara memetik polong kacang hijau pada pagi hari saat udara masih lembab untuk menghindari agar polong tidak pecah saat pemanenan. Polong kemudian dijemur selama 2-3 hari dibawah terik sinar matahari hingga kering. Kemudian pengambilan biji dilakukan secara manual yaitu polong yang telah kering dipukul-pukul dengan tongkat kayu dalam kantong untuk menghindari kehilangan hasil dan biji dipisahkan dari kulit polong dengan cara ditampi.

Adapun variabel yang diamati terhadap 5 tanaman sampel yang dipilih secara acak dari tiap unit percobaan adalah: tinggi tanaman, diameter batang, jumlah daun, tingkat kehijauan daun, umur berbunga, umur panen, jumlah polong per tanaman, bobot polong per tanaman, bobot biji per tanaman, bobot berangkasan segar, bobot berangkasan kering, dan indeks panen. Data yang diperoleh dianalisis varian (ANAVA) pada taraf 5\% menggunakan program statistik. Apabila berbeda nyata akan dilanjutkan dengan analisis Duncan's Multiple Range Test (DMRT) untuk genotipe dan Polinomial Ortogonal (PO) untuk dosis pupuk kandang sapi.

\section{HASIL DAN PEMBAHASAN}

Hasil analisis keragaman menunjukkan adanya interaksi antara dosis pupuk kandang sapi dengan genotipe terdapat pada variabel jumlah daun. Dosis pupuk kandang sapi berpengaruh nyata terhadap variabel tinggi tanaman, tingkat kehijauan daun, umur panen, dan bobot brangkasan segar. Genotipe berpengaruh nyata terhadap tinggi tanaman, diameter batang, tingkat kehijauan daun, umur berbunga, umur panen, jumlah polong per tanaman, bobot polong per tanaman, bobot biji per tanaman, bobot brangkasan segar, bobot brangkasan kering, dan indeks panen (Tabel 1). 
Tabel 1. Rangkuman hasil analisis varian perlakuan dosis pupuk kandang sapi terhadap pertumbuhan dan hasil genotipe kacang hijau.

\begin{tabular}{llcc}
\hline Variabel yang diamati & Dosis & $\begin{array}{c}\text { Nilai } \mathrm{F}_{\text {hitung }} \\
\text { Genotipe }\end{array}$ & Interaksi \\
\hline Tinggi tanaman & $6.33 *$ & $4.72 *$ & $1.21 \mathrm{~ns}$ \\
Diameter batang & $3.88 \mathrm{~ns}$ & $4.12 *$ & $1.18 \mathrm{~ns}$ \\
Jumlah daun & $4.33 \mathrm{~ns}$ & $3.58 *$ & $1.92 *$ \\
Tingkat kehijauan daun & $10.81 *$ & $1.93 *$ & $1.42 \mathrm{~ns}$ \\
Umur berbunga & $0.80 \mathrm{~ns}$ & $81.96 *$ & $0.17 \mathrm{~ns}$ \\
Umur panen & $5.76 *$ & $12.51 *$ & $1.16 \mathrm{~ns}$ \\
Jumlah polong per tanaman & $1.34 \mathrm{~ns}$ & $6.99 *$ & $1.12 \mathrm{~ns}$ \\
Bobot polong per tanaman & $1.24 \mathrm{~ns}$ & $3.69 *$ & $0.98 \mathrm{~ns}$ \\
Bobot biji per tanaman & $1.35 \mathrm{~ns}$ & $3.51 *$ & $0.91 \mathrm{~ns}$ \\
Bobot berangkasan segar & $5.54 *$ & $4.72 *$ & $0.90 \mathrm{~ns}$ \\
Bobot berangkasan kering & $3.63 \mathrm{~ns}$ & $4.30 *$ & $1.01 \mathrm{~ns}$ \\
Indeks panen & $2.68 \mathrm{~ns}$ & $8.05 *$ & $1.18 \mathrm{~ns}$ \\
Keterangan : = Berpengaruh nyata pada uji $\mathrm{F}$ taraf $5 \%$, \\
\multicolumn{1}{c}{ ns = Berpengaruh tidak nyata pada uji F taraf $5 \%$} &
\end{tabular}

\section{Interaksi dosis pupuk kandang sapi de- ngan genotipe kacang hijau}

Berdasarkan hasil analisis varian interaksi antara dosis pupuk kandang sapi dengan genotipe kacang hijau pada variabel jumlah daun, terdapat perbedaan pola respon jumlah daun antar genotipe terhadap peningkatan dosis pupuk kandang sapi yang berbeda-beda. Hal ini karena genotipe memiliki kamampuan yang berbeda-beda dalam menyerap unsur hara dalam tanah. Menurut Poespodarsono (2005), genotipe mempunyai kamampuan yang berbedabeda untuk menyesuaikan diri terhadap lingkungan tempat tumbuhnya. Perbedaan genotipe menunjukkan pertumbuhan jumlah daun dengan pola respon kuadratik dan linear terhadap peningkatan dosis pupuk kandang sapi. Hal ini sesuai dengan hasil penelitian Tawakal (2009), bahwa pemberian pupuk kandang sapi sebagai perlakuan berpengaruh nyata terhadap variabel jumlah daun dan umur berbunga pada pertanaman kedelai. Daun merupakan salah satu organ penentu tingkat produksi tanaman, karena perannya sebagai penyerap dan pengubah energi cahaya matahari pada proses fotosintesis.
Genotipe VR 3, VR 88, VR 200, VR 266 ct, dan VR 601 m menunjukkan pola respon secara kuadratik, sedangkan genotipe VR 61, VR 204 K, VR 213 K, VR 341, VR 368, VR 222 Walet, dan VR 1074 Vinna-1 menunjukkan pola peningkatan pertumbuhan jumlah daun secara linear. Genotipe VR $3\left(\mathrm{G}_{1}\right)$ menunjukkan pola respon pertumbuhan jumlah daun tertinggi secara kuadratik dengan persamaan $\mathrm{Y}=$ $2.6933+0.6089-0.0444 \mathrm{x}^{2}\left(\mathrm{R}^{2}=0.6473\right)$. Dosis pupuk kandang sapi sebagai perlakuan memberikan kontribusi sebesar $64.73 \%$ terhadap variabel pertumbuhan jumlah daun genotipe VR 3. Pertumbuhan jumlah daun pada genotipe VR 3 mencapai maksimal pada pemberian dosis pupuk kandang sapi 6.86 ton $\mathrm{ha}^{-1}$ yaitu sebesar 4.8 tangkai/tanaman. Menurut Murbandono (2005), bahan organik dapat berperan langsung sebagai sumber hara tanaman dan secara tidak langsung dapat menciptakan suatu kondisi lingkungan pertumbuhan tanaman yang lebih baik, yaitu dengan meningkatkan ketersediaan hara untuk mendukung pertumbuhan tanaman. Genotipe VR $368\left(\mathrm{G}_{9}\right)$ memberikan pola respon pertumbuhan jumlah daun terendah 
terhadap peningkatan dosis pupuk kandang sapi dengan pola pertumbuhan secara linear dengan persamaan $\mathrm{Y}=3.2533+0.0622 \mathrm{x}$ $\left(\mathrm{R}^{2}=0.1230\right)$. Peningkatan jumlah daun pada genotipe VR 368 bertambah rata-rata sebesar 0,06 tangkai setiap penambahan dosis pupuk kandang sapi 1 ton $\mathrm{ha}^{-1}$. Dosis pupuk kandang sapi memberikan kontribusi sebesar $12.30 \%$ terhadap pertumbuhan jumlah daun pada genotipe VR 368. Kualitas dan kuantitas daun akan menjadi penentu tingkat produksi tanaman, karena perannya sebagai penyerap dan pengubah energi cahaya matahari pada proses fotosintesis. Menurut Sundari et al. (2005), kualitas dan kuantitas cahaya matahari yang diterima oleh tanaman terhadap penaungan dapat mempengaruhi hasil produksi biji kacang hijau.

\section{Pertumbuhan dan hasil kacang hijau pada berbagai taraf dosis pupuk kan- dang sapi}

Pemberian dosis pupuk kandang sapi nyata berpengaruh terhadap tinggi tanaman, tingkat kehijauan daun, umur panen, dan bobot brangkasan segar (Tabel 1). Wiroatmodjo et al. (1990), menyatakan bahwa penggunaan pupuk organik akan dapat mendorong perkembangan akar dan berfungsi menyerap hara dan air untuk pertumbuhan tanaman. Menurut Ismail et al. (2014) pemberian pupuk kandang sapi pada pertumbuhan kacang panjang berpengaruh nyatauntuk parameter tinggi tanaman, panjang polong, berat polong, dan jumlah polong.

Berdasarkan hasil analisis regresi, tinggi tanaman meningkat seiring dengan peningkatan dosis pupuk kandang sapi secara linear dengan persamaan $\mathrm{Y}=8.6493$ $+0.4698 \mathrm{x}\left(\mathrm{R}^{2}=0.4659\right)$. Tinggi tanaman berkaitan dengan hasil kacang hijau seperti jumlah polong, bobot polong, dan bobot biji per tanaman.

Dosis pupuk kandang sapi sebagai perlakuan memberikan kontribusi sebesar $46.59 \%$. Dari persamaan tersebut setiap penambahan pupuk kandang sapi 1 ton ha $^{-1}$ akan menambah tinggi tanaman ratarata sebesar $0.47 \mathrm{~cm}$. Tinggi tanaman akan meningkat dengan pemberian dosis pupuk kandang sapi 9 ton $\mathrm{ha}^{-1}$. Menurut Sitompul dan Guritno (1995), tanaman yang aktif dalam melakukan proses fotosintesis akan memacu pertumbuhan tinggi tanaman, jumlah daun, jumlah akar, panjang akar, berat segar tanaman dan pada akhirnya dapat meningkatkan berat kering tanaman.

Kehijauan daun meningkat seiring dengan peningkatan dosis pupuk kandang sapi. Pemberian pupuk kandang sapi dapat menambah unsur hara nitrogen dalam tanah. Menurut Fitrianah et al. (2012), unsur nitrogen lebih banyak berperan pada fase pertumbuhan vegetatif tanaman seperti pembentukan zat kehijauan daun (klorofil) yang dibutuhkan tanaman dalam proses fotosintesis. Kehijauan daun berkaitan dengan potensi hasil kacang hijau seperti jumlah polong per tanaman, bobot polong per tanaman, dan bobot biji per tanaman.

Berdasarkan analisis regresi, terdapat peningkatan kehijauan daun terhadap penambahan dosis pupuk kandang sapi secara linear dengan persamaan $\mathrm{Y}=38.81$ $+1.0037 \mathrm{x}\left(\mathrm{R}^{2}=0.3109\right)$, dosis pupuk kandang sapi memberikan kontribusi sebesar $31.1 \%$ terhadap peningkatan zat kehijauan daun kacang hijau. Respon umur panen pada pemberian dosis pupuk kandang sapi secara linear dengan persamaan $\mathrm{Y}=$ 53.886-0.2116x $\left(\mathrm{R}^{2}=0.0768\right)$. Perlakuan dosis pupuk kandang sapi memberikan kontribusi sebesar $7.68 \%$, dan setiap penambahan pupuk kandang sapi 1 ton ha-1 akan mempercepat umur panen pertama rata-rata 0.2 hari. Hal ini diduga karena unsur hara dari pupuk kandang sapi yang diberikan telah habis dan sebagian tercuci oleh air hujan yang turun. Sesuai dengan penelitian Ratri (2009), setelah pupuk 
kandang sapi didekomposisikan selama dua bulan dan diproses menjadi pupuk cair kandungan hara terlarutnya mengalami penurunan.

Bobot brangkasan segar kacang hijau meningkat seiring dengan peningkatan dosis pupuk kandang sapi. Hal ini dikarenakan unsur hara nitrogen yang terkandung pada pupuk kandang sapi dan dalam tanah tinggi. Menurut Susilo (1991), keberadaan nitrogen yang cukup dalam tanah dapat meningkatkan sintetis protein untuk pembelahan dan pembesaran sel yang menyebabkan bertambahnya jumlah dan peningkatan ukuran sel sehingga bobot berangkasan segar meningkat.

Adanya peningkatan secara signifikan bobot brangkasan segar tanaman terhadap penambahan dosis pupuk kandang sapi secara linear dengan persamaan $\mathrm{Y}=$ $3.1002 x+12.33\left(\mathrm{R}^{2}=0.3086\right)$. Perlakuan dosis pupuk kandang sapi memberikan kontribusi sebesar $30.86 \%$ terhadap bobot brangkasan segar tanaman, dan setiap penambahan pupuk kandang sapi 1 ton ha $^{-1}$ akan meningkatkan bobot brangkasan segar tanaman rata-rata sebesar $3.1 \mathrm{~g}$ per tanaman. Semakin tinggi dosis pupuk kandang sapi yang diberikan akan meningkatkan kandungan nitrogen dalam batang dan daun yang menyebabkan jumlah protein lebih banyak, sehingga daun dan batang tumbuh lebih besar dan berat tanaman total meningkat (Hakim et al., 1989). Nitrogen merupakan unsur yang paling berpengaruh terhadap pertumbuhan vegetatif tanaman, kandungan nitrogen yang cukup besar dalam pupuk kandang sapi yang diberikan sebagai perlakuan dapat meningkatkan unsur hara nitrogen dalam tanah.

\section{Pertumbuhan dan hasil 12 genotipe ka- cang hijau}

Penggunaan genotipe kacang hijau yang berbeda berpengaruh nyata pada semua variabel pengamatan tinggi tanaman, diameter batang, tingkat kehijauan daun, umur berbunga, umur penen, jumlah polong per tanaman, bobot polong per tanaman, bobot biji pertanaman, bobot brangkasan segar, bobot brangkasan kering, dan indeks panen. Hasil analisis keragaman pertumbuhan dan hasil dua belas genotipe kacang hijau (Tabel 2 dan Tabel 3).

Genotipe VR 61 memberikan nilai tertinggi pada variabel tinggi tanaman, menghasilkan polong yang lebih banyak, sehingga bobot polong dan bobot biji keringnya juga tinggi. Namun tinggi tanaman genotipe VR 61 secara signifikan berbeda tidak nyata terhadap genotipe lain kecuali VR 88, VR 200, dan VR 1074 Vinna-1. Jumlah polong genotipe VR 61 berbeda tidak nyata dengan genotipe VR $213 \mathrm{~K}$, serta bobot polong dan bobot biji per tanaman genotipe VR 61 secara signifikan berbeda tidak nyata dengan genotipe VR 3 , VR 88, VR 200, VR 204 K, VR 213 K, VR 341, VR $601 \mathrm{~m}$, dan VR 222 walet. Genotipe VR 266 ct memiliki ukuran polong dan biji yang lebih kecil dibandingkan genotipe yang lainnya, sehingga bobot polong per tanaman, bobot biji per tanaman, dan indeks panennya rendah. Namun genotipe ini memiliki ukuran diameter batang, bobot brangkasan segar dan bobot brangkasan kering tertinggi. Diameter batang dan bobot brangkasan kering genotipe VR 266 ct berbeda tidak nyata dengan genotipe VR 3 dan VR 61 . Genotipe VR $601 \mathrm{~m}$ memiliki ukuran biji yang lebih besar dibandingkan genotipe lain sehingga bobot biji per tanaman dan indeks panennya tinggi. Bobot biji per tanaman dan indeks panen genotipe VR 601 $m$ tidak berbeda secara signifikan dengan genotipe VR 3, VR 88, VR 200, VR $213 \mathrm{~K}$, VR 341, dan VR 222 walet. Genotipe VR $213 \mathrm{~K}$ memiliki umur berbunga dan umur panen tercepat. Genotipe VR 1074 Vinna-1 memiliki fase pertumbuhan vegetatif yang relatif lebih rendah dibandingkan genoti- 
Tabel 2. Keragaan pertumbuhan vegetatif dua belas genotipe kacang hijau di ultisol

\begin{tabular}{llllll}
\hline Genotipe & $\begin{array}{l}\text { Tinggi } \\
\text { tanaman }(\mathrm{cm})\end{array}$ & $\begin{array}{l}\text { Diameter } \\
\text { batang }(\mathrm{mm})\end{array}$ & $\begin{array}{l}\text { Variabel } \\
\text { Tingkat } \\
\text { kehijauan } \\
\text { daun }\end{array}$ & $\begin{array}{l}\text { Bobot } \\
\text { brangkasan } \\
\text { segar }(\mathrm{g})\end{array}$ & $\begin{array}{l}\text { Bobot } \\
\text { brangkasan } \\
\text { kering }(\mathrm{g})\end{array}$ \\
\hline VR 3 & $11.28 \mathrm{ab}$ & $4.81 \mathrm{abc}$ & $46.18 \mathrm{a}$ & $32.61 \mathrm{~b}$ & $6.98 \mathrm{ab}$ \\
VR 61 & $11.68 \mathrm{a}$ & $4.91 \mathrm{ab}$ & $43.49 \mathrm{abc}$ & $34.19 \mathrm{~b}$ & $7.48 \mathrm{ab}$ \\
VR 88 & $10.10 \mathrm{~cd}$ & $4.23 \mathrm{~cd}$ & $43.85 \mathrm{abc}$ & $19.81 \mathrm{~cd}$ & $4.46 \mathrm{~cd}$ \\
VR 200 & $10.03 \mathrm{~cd}$ & $4.22 \mathrm{~cd}$ & $42.67 \mathrm{abc}$ & $20.37 \mathrm{~cd}$ & $4.11 \mathrm{~cd}$ \\
VR 204 K & $11.54 \mathrm{ab}$ & $4.19 \mathrm{~cd}$ & $42.41 \mathrm{abc}$ & $29.17 \mathrm{bc}$ & $5.81 \mathrm{bc}$ \\
VR 213 K & $10.48 \mathrm{bc}$ & $4.20 \mathrm{~cd}$ & $45.46 \mathrm{a}$ & $21.77 \mathrm{~cd}$ & $4.49 \mathrm{~cd}$ \\
VR 266 ct & $11.08 \mathrm{abc}$ & $5.26 \mathrm{a}$ & $41.20 \mathrm{bc}$ & $44.06 \mathrm{a}$ & $8.42 \mathrm{a}$ \\
VR 341 & $11.33 \mathrm{ab}$ & $4.39 \mathrm{bcd}$ & $42.84 \mathrm{abc}$ & $25.47 \mathrm{bcd}$ & $5.27 \mathrm{bcd}$ \\
VR 368 & $10.63 \mathrm{abc}$ & $4.00 \mathrm{~d}$ & $40.22 \mathrm{c}$ & $21.49 \mathrm{~cd}$ & $4.35 \mathrm{~cd}$ \\
VR 601 m & $11.40 \mathrm{ab}$ & $4.25 \mathrm{~cd}$ & $43.52 \mathrm{abc}$ & $24.63 \mathrm{bcd}$ & $4.66 \mathrm{~cd}$ \\
VR 222 walet & $10.62 \mathrm{abc}$ & $4.39 \mathrm{bcd}$ & $44.40 \mathrm{ab}$ & $25.58 \mathrm{bcd}$ & $5.50 \mathrm{bcd}$ \\
VR 1074 & $9.02 \mathrm{~d}$ & $3.88 \mathrm{~d}$ & $43.67 \mathrm{abc}$ & $16.18 \mathrm{~d}$ & $3.31 \mathrm{~d}$ \\
Vinna-1 & & & & &
\end{tabular}

Keterangan : Angka-angka yang diikuti oleh huruf yang sama pada kolom yang sama berbeda tidak nyata pada DMRT taraf $5 \%$

Tabel 3. Keragaan pertumbuhan generatif dan komponen hasil dua belas genotipe kacang hijau di ultisol

\begin{tabular}{lllllll}
\hline Genotipe & $\begin{array}{l}\text { Umur } \\
\text { berbunga } \\
\text { (hst) }\end{array}$ & $\begin{array}{l}\text { Umur } \\
\text { panen (hst) }\end{array}$ & $\begin{array}{l}\text { Jumlah } \\
\text { polong }\end{array}$ & $\begin{array}{l}\text { Bobot } \\
\text { polong } \\
(\mathrm{g})\end{array}$ & $\begin{array}{l}\text { Bobot biji } \\
\text { per tanaman } \\
(\mathrm{g})\end{array}$ & $\begin{array}{l}\text { Indeks } \\
\text { panen (\%) }\end{array}$ \\
\hline VR 3 & $31.8 \mathrm{de}$ & $53.2 \mathrm{bc}$ & $7.4 \mathrm{bcd}$ & $6.3 \mathrm{ab}$ & $4.9 \mathrm{a}$ & $40.2 \mathrm{abc}$ \\
VR 61 & $32.7 \mathrm{~cd}$ & $54.2 \mathrm{~b}$ & $11.1 \mathrm{a}$ & $6.9 \mathrm{a}$ & $5.1 \mathrm{a}$ & $40 \mathrm{bcd}$ \\
VR 88 & $31.3 \mathrm{de}$ & $52.8 \mathrm{bcd}$ & $5.1 \mathrm{cde}$ & $5.6 \mathrm{abc}$ & $4.5 \mathrm{ab}$ & $45.8 \mathrm{ab}$ \\
VR 200 & $36.0 \mathrm{~b}$ & $53.6 \mathrm{~b}$ & $4.8 \mathrm{e}$ & $4.8 \mathrm{bc}$ & $3.9 \mathrm{ab}$ & $45.6 \mathrm{ab}$ \\
VR 204 K & $33.3 \mathrm{c}$ & $51.7 \mathrm{de}$ & $8.7 \mathrm{~b}$ & $5.8 \mathrm{abc}$ & $4.3 \mathrm{ab}$ & $37.5 \mathrm{~cd}$ \\
VR 213 K & $31.0 \mathrm{e}$ & $51.0 \mathrm{e}$ & $8.9 \mathrm{ab}$ & $5.5 \mathrm{abc}$ & $3.9 \mathrm{ab}$ & $42.5 \mathrm{abc}$ \\
VR 266 ct & $38.3 \mathrm{a}$ & $57.6 \mathrm{a}$ & $4.8 \mathrm{e}$ & $2.8 \mathrm{~d}$ & $2.0 \mathrm{c}$ & $19.3 \mathrm{e}$ \\
VR 341 & $32.7 \mathrm{~cd}$ & $51.3 \mathrm{e}$ & $7.2 \mathrm{bcde}$ & $5.9 \mathrm{abc}$ & $4.6 \mathrm{ab}$ & $42.7 \mathrm{ab}$ \\
VR 368 & $32.0 \mathrm{cde}$ & $52.1 \mathrm{cde}$ & $7.6 \mathrm{bcd}$ & $4.3 \mathrm{~cd}$ & $3.1 \mathrm{bc}$ & $34.7 \mathrm{~d}$ \\
VR 601 m & $36.0 \mathrm{~b}$ & $51.8 \mathrm{cde}$ & $7.8 \mathrm{bc}$ & $6.3 \mathrm{ab}$ & $4.9 \mathrm{a}$ & $47.9 \mathrm{a}$ \\
VR 222 walet & $33.3 \mathrm{c}$ & $54.1 \mathrm{~b}$ & $6.6 \mathrm{bcde}$ & $5.6 \mathrm{abc}$ & $4.5 \mathrm{ab}$ & $41 \mathrm{abcd}$ \\
VR 1074 Vinna-1 & $31.0 \mathrm{e}$ & $51.9 \mathrm{cde}$ & $4.5 \mathrm{de}$ & $4.2 \mathrm{~cd}$ & $3.2 \mathrm{bc}$ & $46.7 \mathrm{ab}$ \\
\hline
\end{tabular}

Keterangan : Angka-angka yang diikuti oleh huruf yang sama pada kolom yang sama berbeda tidak nyata pada DMRT taraf $5 \%$ 
pe lain, sehingga tinggi tanaman, diameter batang, bobot brangkasan segar, dan bobot brangkasan keringnya juga rendah.

\section{KESIMPULAN}

Dari hasil penelitian dapat disimpulkan bahwa :

1. Antar genotipe terdapat pola respon pertumbuhan jumlah daun yang berbeda terhadap peningkatan dosis pupuk kandang sapi.

2. Genotipe VR 3 memiliki kehijauan daun tertinggi. Genotipe VR 61 memiliki nilai tertinggi pada pertumbuhan tinggi tanaman, jumlah polong, bobot polong, dan bobot biji per tanaman. Genotipe VR 213 K memiliki umur berbunga dan umur panen tercepat. Genotipe VR 266 ct memiliki nilai tertinggi pada variabel diameter batang, bobot brangkasan segar, dan bobot brangkasan kering. Genotipe VR 601 $\mathrm{m}$ menunjukkan nilai tertinggi pada variabel indeks panen.

3. Penggunaan berbagai taraf dosis pupuk kandang sapi berpengaruh nyata terhadap tinggi tanaman, tingkat kehijauan daun, umur panen, dan bobot brangkasan segar.

\section{DAFTAR PUSTAKA}

Adimihardja, A., I. Juarsah, dan U. Kurnia. 2000. Pengaruh penggunaan berbagai jenis dan takaran pupuk kandang terhadap produktifitas tanah ultisol terdegradasi di Desa Batin, Jambi. Hlm: 303-319. Dalam Prosiding Seminar Nasional Sumber Daya Tanah, Iklim, dan Pupuk. Buku II. Lido-Bogor, Pusat Penelitian Tanah dan Agroklimat. Bogor. 6-8 Desember. 1999.
Afif. T., D. Kastono, dan P. Yudono. 2014. Pengaruh macam pupuk kandang terhadap pertumbuhan dan hasil tiga kultivar kacang hijau (Vigna radiata L. Wilczek) di lahan pasir Pantai Bugel Kulon Progo.Vegetalika 3(3): $78-88$.

Atman. 2007. Teknologi budidaya kacang hijau Vigna radiata L. di lahan sawah. J. Ilmiah Tambua 6(1): 89-95.

Direktorat Jendral Tanaman Pangan. 2012. Road map peningkatan produksi kacang tanah dan kacang hijau tahun 2010 - 2014. Kementerian Pertanian. Jakarta.

Fitrianah, L., F. Siti, dan H. Yunin. 2012. Pengaruh komposisi media tanam terhadap pertumbuhan dan kandungan saponin pada dua varietas tanaman gendola (Basella sp). J. Agrovigor 5(1): 34-46.

Hakim, N., M.Y. Nyakfa, A.M. Lubis, S.G. Nugroho, M.R. Saul, M.A. Diha, G.B. Hong, dan Bailey. 1989. DasarDasar Ilmu Tanah. Universitas Lampung. Bandar Lampung.

Hidayah, I. dan A.N. Susanto. 2008. Analisis kelayakan finansial teknologi usahatani kacang hijau setelah padi sawah di Desa Waekasar, Kecamatan Mako, Kabupaten Buru, Maluku. J. Budidaya Pertanian 4(1): 54-63.

Kasno, A. 2007. Kacang hijau alternatif yang menguntungkan ditanam di lahan kering. Tabloid Sinar Tani 23 Mei 2007. Jakarta.

Ismail, M.R., N. Pomalingo, dan Nurmi. 2014. Pengaruh pupuk kandang sapi terhadap pertumbuhan dan hasil ta- 
naman kacang panjang (Vigna sinensis L.). Skripsi. Universitas Negeri Gorontalo. Gorontalo. (tidak dipublikasikan).

Mulyani, A., Hikmatullah, dan H. Subagyo. 2004. Karakteristik dan potensi tanah masam lahan kering di Indonesia. hlm. 1-32 dalam Prosiding Simposium Nasional Pendayagunaan Tanah Masam. Pusat Penelitian dan Pengembangan Tanah dan Agroklimat. Bogor.

Murbandono, L. 2005. Membuat Kompos. Agro Media Pustaka. Jakarta.

Musnawar, E.I. 2006. Pupuk Organik Cair dan Padat, Pembuatan dan Aplikasi. Penebar Swadaya. Jakarta.

Nurmawati, S. dan S. Anang. 2000. Studi perbandingan penggunaan pupuk kotoran sapi dengan pupuk kascing terhadap produksi tanaman selada (Lactuca sativa Var.crispa) Laporan Penelitian. Fakultas Matematika dan Ilmu Pengetahuan Alam. Pusat Penelitian Indonesia Universitas Terbuka (PSI-UT). Jakarta.

Poespodarsono. 2005. Dasar-dasar Ilmu Pemuliaan Tanaman. PAU-IPB. Bogor.

Ratri, D.T. 2009. Pengaruh konsentrasi larutan pupuk kandang sapi sebagai pupuk daun organik terhadap pertumbuhan dan produksi dua varietas kedelai (Glycine max (L) Merr). Skripsi. Jurusan Budidaya Pertanian. Fakultas Pertanian. Institut Pertanian Bogor, Bogor. (tidak dipublikasikan).
Gadjah Mada. University Press. Yogyakarta.

Subowo, J. Subaga, dan M. Sudjadi. 1990. Pengaruh bahan organik terhadap pencucian hara tanah ultisol Rangkasbitung, Jawa Barat. Pemberitaan Penelitian Tanah dan Pupuk 9: 26-31.

Sundari, T., Soemartono, Tohari, dan W. Mangoendidjojo. 2005. Keragaan hasil dan toleransi genotipe kacang hijau terhadap penaungan. J. Ilmu Pertanian 12(1): 12-19.

Susilo, H. 1991. Fisiologi tanaman budidaya. Universitas Indonesia. Press Salema. Jakarta.

Tawakal, M.I. 2009. Respon pertumbuhan dan produksi beberapa varietas kedelai (Glicine $\max$ L.) terhadap pemberian pupuk kandang sapi. Skripsi. Fakultas Pertanian. Universitas Sumatra Utara. Medan. (tidak dipublikasikan).

Utomo, B. 2008. Perbaikan sifat tanah ultisol untuk meningkatkan pertumbuhan Eucalyptus urephilla pada ketinggian 0-400 meter. Staf Pengajar Departemen Kehutanan. Fakultas Pertanian. Universitas Sumatera Utara. Medan.

Wiroatmodjo, J., E. Sulistyono, dan Hendrinova. 1990. Pengaruh berbagai pupuk organik dan pupuk daun terhadap pertumbuhan dan hasil rimpang jahe (Zingiber officinale R.) jenis Badak. Buletin Agronomi 19(1): 33-38.

Sitompul, S.M., dan B. Guritno. 1995. Analisis Pertumbuhan dan Tanaman. 